\title{
The construction and validation of solution-focused group work (SFGW) for Malaysian adolescents
}

\author{
Ratnadevi R. Shunmugam ${ }^{*} 1$ \& Sidek Mohd Noah ${ }^{2}$ \\ ${ }^{12}$ Faculty of Educational Studies, University of Putra Malaysia \\ ${ }^{*}$ Corresponding author, $\equiv$ e-mail: ratnadevirshunmugam@gmail.com
}

\begin{abstract}
Solution-focused Group Work (SFGW) approach is proven to be effective in resolving adolescents' life struggles and assist them to lead a successful adolescence hood. Common practices of developing the intervention module and assessing the module are presented in this study. The data was collected by two stages: (i) validation process by 4 counseling module development experts; and (ii) a total of 30 samples aged 14-15 years old was piloted to obtain the reliability score of SFGW. The collected data were subjected to descriptive test. The result yielded that SFGW have good validity and high reliability with Cronbach's alpha of .87 and .94 respectively. Hence, it is concluded that SFGW is a valid and reliable module for adolescents who increases their self-efficacy, achievement motivation and goalsetting behaviors.
\end{abstract}

Keywords: Solution-focused Group Work (SFGW), Adolescents

How to Cite: Shunmugam, R.R., \& Noah, S.M. (2017). The construction and validation of solutionfocused group work (SFGW) for Malaysian adolescents. Couns-Edu: International Journal of Counseling and Education, 2(2): pp. 48-56. DOI: https://doi.org/10.23916/002017028920

This is an open access article distributed under the Creative Commons Attribution License, which permits unrestricted use, distribution, and reproduction in any medium, provided the original work is properly cited. (C2017 by author and Indonesian Counselor Association (IKI).

\section{Introduction}

It is timely that Ministry of Education has had introduced National Educational Blueprint $2013-2025$ with one of the focus is to produce a well-informed students, be it academically or non-academically. Schools are encouraged to create a harmonious environment for students to explore themselves and provide opportunities for them to correct their behavior. Since adolescence is a crucial stage to develop their strengths towards positive living, they need to be empowered with confidence and ability to figure out solutions for their own problems (Morton \& Montgomery, 2013).

Mahzam (2013) suggested that students should be given a continuous guidance and assistance to develop their life skills. Borhan, L., Hashim F., \& Othman J (2014) recommended schools to provide support and opportunities to adolescents to explore and form their identity through co-curricular and instructional approach. Acquiring adequate skills will empower students to face challenges in life positively. Ultimately, students with stable mental state will contribute to the wellness of themselves as well as their environment like schools. Students who have a clear understanding on themselves and equipped with necessary skills to face challenges will later increase their academic achievement and decrease disciplinary problems in school setting (Mahzam, 2013). Engaging in group work and role playing activities will provide a platform for adolescents to make real-world decisions on matters like sex and drugs (Santrock, 2013). 
As to assist and uphold the importance of counseling, numerous studies conducted in school setting. In recent years, research on counselors' competency, effectiveness of counseling and various intervention modules were validated and tested its reliability in school setting (Bavani \& Sorooshian 2012; Mohamad, Z., Hj, A., \& Rahman, A., 2011; Mahzam, 2013; Amalie Madihie \& Sidek Mohd Noah, 2013). With this progress in mind, counselors may reach more students to assist them in their positive personal development. Programs based on group works found to be effective as adolescents are more contented to express themselves in the peer groups (Corey, 2012). As to laud the need for interventions, current move to develop an intervention program using SFGW in Malaysian context is much welcomed. Intervention using SFGW approach proven to be effective in resolving adolescents struggles in life like low self-esteem and depression (Javanmiri L. et.al, 2013; Mahzam, 2013; Reddy et.al, 2015). Hence, integration between solution-focused approach and group work will definitely be anticipated in providing a solid intervention in Malaysian schools.

\section{Theoretical Foundation of SFGW}

Solution-focused is a post-modern therapeutic approach which emerged in 1980s. The approach strongly influenced by the work of Milton Erikson and the MRI Group in Palo Alto, CA. The distinguish aspect of the approach is the use of artful vague language and well-crafted statements to allow the client to come up with their own understanding. Steve De Shazer and Insoo Kim Berg spent more than 25 years with clients by observing and paying attention to what was most useful to promote solutions. They are in the opinion that sessions are meant to help satisfy what clients wanted and subsequently creating solutions within the short period of time. Following tenets explain the reasons behind the selection of the theory as a guideline in development of SFGW.

One of the solution-focused basic tenets is the identification of positive signs in individual. Clients are seen as the nuclease of the session that always cooperative. They are viewed as the expert of their own life and change happens as client experience themselves as competent and successful. Counselor and client identify exceptions to most problems put forward and look for solutions. Problems are viewed as a way of describing things rather than pathology and complex problems not necessarily needs complex solutions. This approach ought to facilitate changes in clients, in the way chosen by them. Small change in thought or act can lead to larger change in client life.

This is a straight forward, time effective, efficient, and positive psychological approach towards solutions for any situations faced by clients. The approach is differed from traditional counseling psychotherapy approaches in that it shifts the focus from problem solving to solution focus (Sobhy \& Cavallaro, 2010; Saadazaade \& Khalili, 2012). Counselors do not necessarily need to know the pathology of clients but to collaborate on signs of when the problem has been solved (Sobhy \& Cavallaro, 2010).

Hence, this positive based orientation views people as competent and has the strength to construct solutions for their well-being. Solution-focused theory interpret that people have all the capability to find solution but sometimes tend to lose awareness of their competencies. The therapeutic tasks provided in the session aimed to shift from past-oriented focused to present and future. The belief here is that of clients are able to identify and specifically present the problems and goals and also pronounce the positive changes encountered during the process. The emphasis on the positive changes actually leads towards solutions in the session.

This simple, fast and client centered theory views clients as always cooperating in the sessions. The clients are recognized as the expert in their own life. This futuristic based theory focuses on the positive side of life, and always looks for solution. In addition, the theory facilitates and guides a person towards a positive change in their desired direction. It assumes that a small change may lead to larger change in a persons' life. This assumption based on the facts that change happens as people experience themselves as competent and successful. And, its view about problem significantly differentiates it from other theories. Complex problems not necessarily need a complex solution. It focuses on how to solve the problem rather that questioning the reason on why the problem occurs. Exceptions to most problems can be identified by counselors and clients.

Here, the duty of solution-focused counselors is, help the clients to recover their lost awareness by using the techniques in theory. The techniques used are goal setting, the miracle question, exception questions, scaling questions, coping questions, relationship questions and the therapeutic feedback. The reaction 
towards the techniques builds an active and directive approach (Sobhy \& Cavallaro, 2010). The utilization of the techniques based on seven principles of solution focus approach. They are 1) to change the interaction pattern and aware the limitation in relationship with others; 2) to encourage a person to do something differently; 3) to establish an accommodating relationship with clients; 4) to derive new and useful meaning from client's complaints; 5) to look for clients' small changes; 6) the emerge of small changes is enough to create changes in the whole system of the clients' life; and 7) it is not a mandate for counselors to know deep about the clients' problems.

Corey (2008) modified the basic assumption of SF to suit the group counseling. They are (1) changes are expected to occur with the focus on the future and solution bases; (2) group members are blocked with negative thought for progress despite their high capability of resolving issues; (3) exceptions exist for every problems, thus focus on exceptions will lead to solutions; (4) clients given opportunity to present their other sides of the self; (5) a small changes recognized as this will lead to other changes; (6) group leaders should facilitate clients desire to change; and (7) groups members can be trusted in their intention to find solution that uniquely suits themselves.

Gerald B.S. (2005) concluded that adolescents do not have the cognitive skills needed to understand where and how they get into the problem as the way adults are able to grasp the nature of the problem. As the SF uses the clients' words, counseling became easier for adolescents to comprehend. Counseling becomes more personalized and met the needs of students as the counselors use students language. Students' ability to communicate at their level and to recognize that they are understood creates and ideal situation. Another aspect is the focus on language that directs them to take positive actions (Gerald B.S., 2005). The qualitative data of conversation analysis revealed SFGW influenced and gradually changes adolescents' problem based speeches to a more solution focused and hope for success conversation. He further said that specific SFGW techniques like miracle questions, scaling questions, and exceptions able to bring a solution for clients. The research proved that low self-esteem clients could utter high self-esteem speeches after SFBT intervention (Mulawarman, 2014).

The above discussion clearly stated that adolescents are able to lead a constructive lifestyle with guidance from adults through education. Group work activity, based on well researched modules would benefits adolescents a lot. SF tenets found to be adequately assist adolescents to create their life purpose and built a solid life foundation. The goal-setting, exception and change variables derived from SF will be used in this study. The development of SFGW module would be a great platform for all the stakeholders for empowering adolescents in Malaysia.

A good module development should be based on theoretical background (Rozubi \& Lau P.L., 2015). As for the study, Solution-Focused Theory will ground the SFGW module development. The module grounded by Solution-focused tenets could explain the empowerment of adolescents to focus on solutions to their problems. Adolescents would be empowered by encouraging them to plan, set goals, to experience, to review goals, reframed obstacles and celebrate little change observed by them.

On the whole, Solution-focused literature can be categorized into two broad themes. These are, firstly, solution construction using the goal-setting and self- regulation. Secondly, create exceptions to the problem and utilizing of strengths available within individuals (Grant, 2011). Grant (2012) focused on three key factors: (1) goal orientation; (2) resource activation and (3) problem disengagement in the development of solution-focused inventory. Henceforth, current study suggests fourth theme focusing on the capacity of the person to recognize positive change. The notification of positive change in individuals will motivate and encourage them to pursue life positively. Such encouragement is seemed a must for adolescents to see life positively. This would empower them with the sense of objectiveness, self-efficacy and motivation to achieve successful and healthier life.

In conclusion, the study will develop a personal development module based on four core themes drawn from literature review of Solution-focused theory. The themes are named as (1) Goal-Setting (GS); (2) Resource Activation (RA); (3) Solution-Focused (SF) and (4) Positive Change (PC).

\section{The Need to Develop the SFGW Module}

The need to develop the module was felt, mainly for three reasons. Firstly, study by local researchers suggests more preventive programs being developed for Malaysian adolescents so that, Malaysia can 
produce a better future generation (Abdul Hamid et.al., 2015). There is a gap in youth programs that focus on values and moral's education and life competency skills on how to behave (Abdullah et.al., 2015).

Secondly, adolescents are viewed as competent and full of ability to endure their lives journey (Moshman, 2011 \& Santrock, 2013). They have inner strength for achievement to lead their life. To lead a successful adolescence hood, they need psychological, social and other related supports from adult (Santrock, 2013). All they need is affirmation on their capability in accomplishing given tasks, ability to construct goals of their own and constant motivation to achieve goals. The integration of self-efficacy and goal-setting techniques would be beneficial to increase achievement motivation among adolescents (Zimmerman, 1992). Hence, the module developed will look into adolescent's self-efficacy, goal-setting behavior and achievement motivation grounded by Solution-Focused theory.

Thirdly, to date, in attempt to address issues related to adolescents, local researchers documented numbers of studies which mainly pay attention to the outcome of interventions using various theories and approaches like Cognitive-Behavioral Therapy and Rational Emotive Therapy (Mahzam, 2013; Madihie, A., \& Mohd Noah, S., 2013) Most of these studies focused on the effectiveness of such approaches on adolescents' academic achievement, self-esteem and self-efficacy. Unfortunately, only handful of these studies focused on the effectiveness of Solution-Focused group work intervention among adolescents, especially academic achievement. Thus, current study is in the hope to fill in such a loop in counseling intervention field. The study will reveal the effectiveness of Solution-focused group work on adolescence goal-setting behavior, self-efficacy and achievement motivation.

\section{Method}

As to determine the validity and reliability of the drafted module, validation and reliability processes involved. The processes are explained as follows:

\section{Process 1 - Validation Process.}

Experts in the field of counseling and module development were identified. The experts have more than 10 years' experience in module development and two of them have the competency in SolutionFocused theory. The other two experts were involved extensively in counseling development in Malaysia. Researchers identified 6 potential counseling experts and sent an email to seek willingness to evaluate the module. All 5 of them responded and agreed to become the evaluator. An appointment letter was prepared by the second author and sent to respective evaluator with the module draft and the validation form. After two weeks, researcher sent an email to remind about the evaluation, and after a month 3 evaluators returned the module. In between that period of time, evaluators provided feedback via phone calls and emails. One of the evaluator asked the researcher to meet personally to get the feedback and collect the module and validation form. Within a month 3 evaluators responded and return the module with validation form. The fourth evaluator sent in the module after two months but the fifth evaluator unable to accomplish the evaluation due to some personal reason. Finally, data were collected from 4 experts and analysis to get the validation percentage. The analysis was performed and calculated by using percentage (\%). The formula was formulated by SidekMohd Noah and Jamaludin Ahmad (2005) and presented below:

$$
\frac{\text { Total Score from Experts }(\mathrm{x})}{\text { Maximum Score }(100)} \times 100 \%=\text { Content Validity Achievement }
$$

A good content validity should score more than $70 \%$ and if the less than that, the module does not have a good validity result and it is advisable to recheck the content according to the objective of study. Apart from percentage, the result can be presented in a point form, where $100 \%$ as 1.00 and $0 \%$ as 0.00 . This way of writing is similar to a correlation index (SidekMohd Noah and Jamaludin Ahmad, 2005).

Process II - Reliability Measuring Process

Pilot test was carried out to reveal the relevancy, appropriateness and usability of the module on intended participants (Arip, M. A. et.al., 2013). Pilot test also provides feedbacks on the aspects that need 
improvement in the module constructed (Ahmad, J., Amat, M. A. C., Yahaya, S. N., Yusof, R., \& Alias, S. R., 2011). A number of 30 adolescents participated for the pilot study. Permission was obtained from the Ministry of Education to conduct the pilot study and research in schools. Permission letter from Ministry of Education was sent out to participating school Principals and upon obtaining the permission, the researcher visited the schools. With the assistance of school counselors, list of participants was obtained. The participants were given explanation about the SFGW program and their consents were secured. A total of 30 samples were used in this pilot study. Permission from the parents obtained and the participants were made aware that their participation was completely voluntary and that they could withdraw from the study at any time. The usual time to complete the form was about 20 minutes. After the recruitment of participants, they went through the following activities:

1. Activity 1 - I Know You, You Know Me; and Yes!! This is my hope. Activity 1 focus on ice-breaking session, where facilitator and members are get to know each other. Then, group members construct their own rules and goals of being in the group.

2. Activity 2 - provides more opportunities to build confidence and competency among members.

3. Activity 3 - Keys to Solution. Activity 3 focuses on finding solutions for obstacles brought by members. Members are expected to be instilled with positive thoughts about self, utilize their strengths and provide exceptions to obstacles.

4. Activity 4 - members will continue to exercise finding solutions for obstacles and start to scale their progress.

5. Activity 5 - members are to point out positive change in them. Members are expected to analysis the change by eliciting, amplifying and reinforcing (EAR).

6. Activity 6 - anticipated to support members to reframe their obstacles and lead them to solution building. The validity and reliability of the instruments is mandate in research.

7. Activity 7 - Let's Party. The aim is to celebrate members' new understanding, achievement and positive change. This activity expected to affirm the success achieved and also to minimize the relapse among members. The emphasis on the positive changes actually leads towards solutions in the session.

After each session, participants were asked to respond to the reliability instrument that developed from objectives of each activity. The evaluation instrument which was adapted from SMDM consists of 20 items. The items in Reliability Measuring form are on a Likert-scale of 1- Strongly Disagree to 5 - Strongly Agree. Finally, module is ready to use after the validity and reliability is determined.

\section{Results and Discussions}

\section{Validation analysis}

Table 2 Division of validity achievement according percentage of four counseling experts

\begin{tabular}{lccc}
\hline Evaluators & $\begin{array}{l}\text { Evaluators Score } \\
(\mathbf{x} / \mathbf{2 5})\end{array}$ & $\begin{array}{l}\text { Total of Validity } \\
\text { Achievement }(\mathbf{\%})\end{array}$ & Validity Index \\
\hline Evaluator 1 & 18 & 72 & .72 \\
Evaluator 2 & 23 & 92 & .92 \\
Evaluator 3 & 25 & 100 & .100 \\
Evaluator 4 & 21 & 84 & .84 \\
\multicolumn{2}{l}{ Total Achievement Average } & $.870=.9\left(1\right.$ d.p. $\left.{ }^{*}\right)$ & \\
\hline
\end{tabular}

The result shows that, overall validity of the module scored is $87 \%$. The highest percentage was given by evaluator $3(100 \%)$, followed by evaluator $2(92 \%)$, evaluator $4(84 \%)$ and lowest percentage by evaluator 1 (72\%). The SFGW validity index obtained an overall total of .9 (1 d.p.).

The overall comments and suggestions from the evaluators are (i) the module is suitable for the intended samples; (ii) to conduct pilot test prior the actual research to avoid any possible hiccups; (ii) steps in activity 1 and 2 looks similar; (iv) to provide sample dialogues in every activity as to guide others especially the module users. In sum, all evaluators agreed that the content of SFGW is related to the 
objective and suitable for adolescents.

\section{Reliability analysis}

The module reliability instrument can be developed by referring the objectives of activities involved or steps in the activities (Jamaludin Ahmad \& Sidek Mohd Noah, 2005). In this study, the reliability instrument was developed using the objectives of the activities. A total of 20 objectives were identified from all 7 activities, hence the reliability instrument consists of 20 items. The Statistical Packages for Social Sciences (SPSS) version 21 was used to determine the Cronbach's Alpha of the module. The analysis revealed that SFGW module score .938 for 20 items. Othman Mohamed (2000) suggests that a module can be accepted only and if the module obtains .90. Hence, the analysis proved that SFGW module has a high reliability which is .94 . This suggests that the module has a consistency and reliable forbe used in school setting.

This study has proven that SFGW module contains good content validity and has high reliability and suitable to be used in school setting. The module too can be conducted for adolescents' especially secondary school students. Therefore, the module can provide insights to counselors in schools to conduct a properly planned and researched module for adolescents. Besides that, (Schunk, 1995) raised concern on the need to conduct research to examine the relationship between motivation, performance and selfefficacy. Training and skills teaching are common practice in school settings but such activities considered insufficient without assessing its effectiveness on students' self-efficacy and their performance. Due to importance should be given for the effect on the training and skills teaching where self-efficacy and performance be measured. Thus, SFGW intervention module not only teaches students skills, but measures how it impacts students' efficacy, and performance. Well planned guidelines like SFGW enable adolescents to cope with life challenges especially negative thoughts that nailed in them since young.

Most of the studies in Malaysia focused on the development and effectiveness of approaches focus upon adolescents' academic achievement, self-esteem and self-efficacy. Unfortunately, only handful of these studies focused on the effectiveness of Solution-Focused group work intervention among adolescents, especially academic achievement. Thus, the development of SFGW module is in the hope to fill in such loop in counseling intervention field. Programs based on group works found to be effective as adolescents are more contented to express themselves in the peer groups (Corey, 2012). As to laud the need for group interventions, the development of intervention program using SFGW module in Malaysian context is needed.

\section{Conclusions}

The development of SFGW module went through a proper validation and reliability process as suggested by the experts in the field. The skills thought in the module will enable adolescents to be ready to start a successful adulthood. Thus, the current module will enhance adolescents' self-efficacy, achievement motivation and goal-setting behavior.

\section{Acknowledgments}

The earlier version of this article was presented in Seminar Guidance and Counseling, $2^{\text {nd }}$ March 2017 , Padang Indonesia. We would like to thank Universiti Putra Malaysia for support and research grant.

\section{References}

A, C. L., \& Sunde, J. (2009). A Solution-focused Approach to Resolving Conflict among Dutch School. Journal of Systemic Therapies Fall, 28(1).

Abd Hamid, S. R., Ismail, K., Saad, S., Ibrahim, M. B., \& Mansur, N. (2015). Are the Malaysian Adolescents' Behavior At-Stake? Mediterranean Journal of Social Sciences, 6(2), 328-346. http://doi.org/10.5901/mjss.2015.v6n2s5p328.

Abdullah, H., Ortega, A., Ahmad, N., \&Ghazali, S. (2015). Aggressive and Delinquent Behavior among High Risk Youth in Malaysia.Asian Social Science, 11(16), 62-73. http://doi.org/10.5539/ass.v11n16p6. 
Aida Idris, Sedigheh Moghavvemi \& Ghazali Musa. (2015). Selected Theories in Social Science Research. University of Malaya Press.

Alderman, M.Kay. (2008). Motivation for Achievement : Possibilities for Teaching and Learning. $3^{\text {rd }}$ Edition. Routledge, Taylor \& Francis Group.

Asbah Razali, Farimah Dokoushkani, Kogilavani Rajendran. (2013). What Does Literature

Bakar, A. R., Mohamed, S., \& N. S. Zakaria. (2011). Work Values of Malaysian School Counselors: It' s Implication on School Counseling. Journal of Sosial Sciences, 7(3), 456-461.

Bandura, A. (1986). Social Foundations of Thoughts and Action: A Social Cognitive Theory.

Bavani, S., Mohan, V. R., \& Sorooshian, S. (2012). Counseling in the Context of Malaysian Living Style... Journal of Basic and Applied Sciences, 6(10), 292-296. Retrieved from http://www.ajbasweb.com/ajbas/2012/October/292-296.pdf.

Che Rozaniza Azizan, Asbah Razali, \& Rajalingam Pillai. (2013). Promoting Positive Mental Health among Students in Malaysia. Psychology and Behavioral Science. Vol. 2. No. 2, pp. 73 - 82. Doi: 10.11648/j.pbs.20130202.18.

Corey, M.S., Corey, G., \& Corey, C,. (2010). Groups: Process and Practice. $8^{\text {th }}$ Edition. Brooks/Cole, Cengage Learning..

Daki, J., \& Savage, R. S. (2010). Solution-Focused Brief Therapy: Impacts on Academic and Emotional Difficulties. The Journal of Educational Research, 103, 309-326. http://doi.org/10.1080/00220670903383127.

Dale H. Schunk. (1984). Enhancing Self-Efficacy and Achievement Through Rewards and Goals: Motivational and Informational Effects. Journal of Educational Research, 78, 29-34. http://doi.org/10.1080/00220671.1984.10885568.

David R. Shaffer \& Katherine Kipp. (2010). Developmental Psychology: Childhood and Adolescence. $8^{\text {th }}$ Edition. Wadsworth, Cengage Learning.

Devswaroop Upadhyay. (2012). Research Methodology in Education. Wisdom Press, India.

Feldman, S. Robert. (2011). Development Across the Life Span. $6^{\text {th }}$ Edition. Prentice Hall, New Jersey.

Elias, H., Mustafa, S. M. S., Roslan, S., \& Noah, S. M. (2011). Motivational predictors of academic performance in end year examination. Procedia - Social and Behavioral Sciences, 29(2010), 1179-1188. http://doi.org/10.1016/j.sbspro.2011.11.352.

Fadlelmula, F. K. (2010). Educational motivation and students' achievement goal orientations.Procedia Social and Behavioral Sciences, 2(2), 859-863. http://doi.org/10.1016/j.sbspro.2010.03.116.

Franklin, Moore, C., Hopson, K., \& Laura.(2008). Effectiveness of Solution-Focused Brief Therapy in a School Setting. Children \& Schools, 30 (1).

Franklin, Streeter, C., Kim, C. L., Tripodi, J. S., \& Stephen J. (2007). The Effectiveness of a SolutionFocused, Public Alternative School for Dropout Prevention and. Children \& Schools, 29 (3).

Gerald B.Sklare. (2005). Brief Counseling That Works: A Solution-Focused Approach for School Counselors and Administers. $2^{\text {nd }}$ Edition. Corwin Press.

Gladding, Samuel T. (2012).Groups: A Counseling Specialty. $6^{\text {th }}$ Edition. Pearson Education, Inc

Javanmiri, L., Kimiaee, S. A., Bahram, \&, Ghanbari, A., \& Abadi, H. (2013). The Study of SolutionFocused Group Counseling in Decreasing Depression among Teenage Girls. International Journal of Psychological Studies, 5(1). http://doi.org/10.5539/ijps.v5n1p105.

Jerrold Lee Shapiro, Lawrence S.Peltz and Susan Bernadett- Shapiro. (1998). Brief Group Treatment; Practical Training for Therapist and Counselors. Brooks/Cole Publishing Company.

Kvarme, L. G. L., Monsen, K. A., \& Eboh, W. O. (2014). Evidence-based solution-focused care for school-age children experiencing cyberbullying: Using the Omaha system to guide and document psychiatric nursing interventions. Journal of Psychosocial Nursing and Mental Health Services. http://doi.org/10.3928/02793695-20131029-02.

Low Suet Fin. (2011). Pembinaandan Pengujian Model Pencapaian Akademik Pelajar Tingkatan Empat di Daerah Klang. Thesis submitted for doctoral degree. Faculty of Education. University of Malaya, Kuala Lumpur.

Lunenburg, Fred C. (2011). Goal-Setting Theory of Motivation. International Journal of Management, Business, and Administration. Volume 15, Number 1, 2011.

M. Muthee, Jessina \& Thomas, I. (2009). Predictors of Achievement Motivation Among Kenyan Adolescents.The Psychespace. Vol. 3, No. 2, 39-44, July 2009. 
Madihie, A., \& Mohd Noah, S. (2013). An application of the Sidek module development in Rebt counseling intervention module design for orphans.Procedia - Social and Behavioral Sciences, 84, 14811491. http://doi.org/10.1016/j.sbspro.2013.06.777

Mahzam Bt Mohd Saad. (2013). The Effects of Cognitive Behavioral Approach in Group Counseling towards Social Anxiety and Self Focus Attention among Adolescents. Thesis submitted for doctoral degree. Faculty of Education.University of Malaya, Kuala Lumpur.

Malaysia Education Blueprint, M. (2013). Malaysia Education Blueprint 2013 - 2025. Education, 27(1), 1268. http://doi.org/10.1016/j.tate.2010.08.007.

Moeller, A. J., Theiler, J. M., \& Wu, C. (2012). Goal Setting and Student Achievement: A Longitudinal Study. The Modern Language Journal, 96(2), 153-169. http://doi.org/10.1111/j.1540-4781.2011.01231.x

Mohamad, Z., Hj, A., \& Rahman, A. (2011). Counseling Practitioners in Malaysia: Socio-Demographic Profile and Theoretical Approcahes in Counseling Process, 2 (22), 184-188.

Mohd Noah, S. \& Ahmad J. ( 2005). Pembinaan Modul: Bagaimana Membina Modul Latihan dan Modul Akademik. University Putra Malaysia.

Morton, M. H. \& Montgomery, P. (2013). Youth Empowerment Programs for Improving Adolescents' Self-Efficacy and Self-Esteem: A Systematic review. Research on Social Work Practice, 23 (1), 22-33. Doi: $10.1177 / 104973151245996$.

Moshman, D. (2011). Adolescent Rationality and Development: Cognition, Morality and Identity. $3^{\text {rd }}$ Edition.,Pychology Press, New York.

Mulawarman Soedjito Taathadi. (2014). Application of Solution-Focused Brief Therapy (SFBT) to Enhance High School Students Self-Esteem: An Embedded Experimental Design. Internatioinal Journal of Psychological Studies; Vol. 6, No.3.

Najeemah Mohd Yusof, . (2006). Patterns of Social Interaction Between Different Ethnic Groups in Malaysian Secondary Schools. Jurnal Pendidik Dan Pendidikan, 21, 149-164.

Pajares F. (2005). Self-Efficacy During Childhood and Adolescence: Implications for Teachers and Parents. In ........... Self-Efficacy Beliefs of Adolescents, 339 - 367, Information Age Publishing.

Pajares, F., \& Usher, E. L. (2008). Self-efficacy, motivation, and achievement in school from the perspective of reciprocal determinism. Advances in Motivation and Achievement. Vol. 15: Social Psychological Perspectives.

Palfrey, J., Gasser, U., Maclay, C., \&Beger, G. (Unicef). (2011). Digital natives and the three divides to bridge. Adolescence -- An Age of Opportunity.

Rahman, A., Zubaidah, S., Jais, S., \& Isa, N. (2014). Competency Level of the Counselor in Secondary Schools in Malaysia. Pensyarah. Ined. Uitm. Edu. My, 2(2), 1-12. Retrieved from http://pensyarah.ined.uitm.edu.my/nfsshared/Upload/Courses/EDU405/Forum/20140401085222 Competency Level of the Counselor in Secondary. Pdf

Reddy, P. D., Thirumoorthy, A., Vijayalakshmi, P., \& Hamza, M. A. (2015). Effectiveness of SolutionFocused Brief Therapy for an Adolescent Girl with Moderate Depression. Indian Journal of Psychological Medicine, 37 (1). http://doi.org/10.4103/0253-7176.150849.

Reiter, M. D. (2010). Solution-Focused Marathon 3333 Solution-Focused Marathon Sessions. Journal of Systemic Therapies, 29(1), 33-49.

Robert L.Smith. (2015). A Contextual Measure of Achievement Motivation: Significance for Research in Counseling. Vistas project sponsored by the American Counseling Association. http://www.counseling.org/knowledge-center/vistas.

Rooholla Saadatzaade \& Shiva Khalili. (2012). Effects of Solution-Focused Group Counseling on Student's Self-Regulation and Academic Achievement. International Journal for Cross-Disciplinary Subjects in Education (IJCDSE), Volume 3, Issue 3, September 2012.

Rozubi, N. C., \& Li, L. P. (2015). Full Length Review Article the Development of Psychological WellBeing Programme Based on Six Factormodel Psychological Well-Being RYFF ( 1989 ), 2 (1989), 11761180.

Rubenstein, E. D., \& Thoron, A. C. (2014). Setting Goals to Promote Academic and Personal Achievement 1, 1-3. IFAS Extension.University of Florida.

Santrock, John W. (2007). Adolescence. $11^{\text {th }}$ Edition. McGraw-Hill International Edition.

Santrock, John W. (2013). Life-Span Development.14th Edition. Mc Graw-Hill International Edition.

Say about Student at Risk? Psychology and Behavioural Sciences. Vol. 2, No. 2, pp. 51-58. Doi:10.11648/j.pbs.20130202.15. 
See, C. M., \& Ng, K. (2010). Counseling in Malaysia: History , Current Status, and Future Trends Malaysia: The Country, 88, 18-22.

Seffetullah Kuldas, Shahabuddin Hashim \& Hairul Nizam Ismail. (2015). Malaysian Adolescents student' needs for enhancing thinking skills, counteracting risk factors and demonstrating academic resilience. International Journal of Adolescence and Youth, Vol. 20, No. 1, 32 - 47, http://dx.doi.org/10.1080/02673843.2014.973890.

Singh, K. (2011). Study of Achievement Motivation in Relation to Academic Achievement of Students. International Journal of Educational Planning \& Administration, 1(2), 161-171.

Sita Chetri. (2014). Achievement Motivation of Adolescents and Its Relationship

Van den Bergh, L., Denessen, E., Hornstra, L., Voeten, M., \& Holland, R. W. (2010). The Implicit Prejudiced Attitudes of Teachers: Relations to Teacher Expectations and the Ethnic Achievement Gap. American Educational Research Journal, 47 (2), 497-527. http://doi.org/10.3102/0002831209353594.

Violeta Enea \& Ion Dafinoiu. (2009). Motivational Solution-Focused Intervention for Reducing School Truancy Among Adolescents. Journal of Cognitive and Behavioral Psychotherapies, 9 (2), 185-198.

With Academic Achievement. International Journal of Humanities and Social Science Invention, ISSN (Online): 2319 -7722, ISSN (Print): 2319-7714, www.ijhssi.org., Volume 3 Issue 6, June 2014, PP. 08 15.

Yusni Mohamad Yusop, Melati Sumari, Fatanah Mohamad, Ahmad Fathy Ibrahim and Krishnamoorty Muniandy (2015). Kebolehgunaan Modul Bimbingan Kelompok Konsep Kendiri terhadap Pelajar Pengenalan; Jurnal Bitara Edisi Khas (Psikologi Kaunseling) Vol 8, 157-170.

Zahra Houshmand Neghabi \& Sudabesh Morshedian Rafiee. (2013). Mediating Effect of Academic Engagement in Relationship between Academic Self-Efficacy and Academic Achievement among Adolescent in Tehran. Life Science Journal 2013; 10 (5s): 393-399. (ISSN: 1545-1003). http://www.americanscience.org. 71.

Zainudin Abu Bakar, Lee Mei Yun, Ng Siew Keow, Tan Hui Li. (2014). Goal-Setting Learning Principles. Journal of Education and Learning. Volume 8(1), pp.41-50.

Zimmerman, Bandura \& Martinez-Pons. (1992). Self-motivation for academic attainment - The role of self-efficacy beliefs and personal goal setting. American Education Research Journal, Fall 1992, Vol. 29, No.3, pp. 663-676. 